Saša Redžić

UDK: 904:726.821"652"(497.11);

Archaeological Institute Belgrade

904:739"652"(497.11)

sasa.redzic@gmail.com

ID BROJ: 196126732

Original research article

Received: July 12, 2011

Accepted: September 05, 2011

\title{
KNEE FIBULAE WITH SPRING AND SEMI-CIRCULAR HEAD PLATE FROM THE TERRITORY OF VIMINACIUM
}

\begin{abstract}
Concentration of knee fibulas with spring and round head plate can be noted especially along the Rhine and the Danube limes, indicating to some authors that they were primarily worn by soldiers. Although the majority of over 80 examples found in Serbia were also discovered within fortresses along the border, one should also mention a number of finds from the inland, denying the previous statement. Most of the presented fibulae were already published, but owing to new publications regarding this topic and some unpublished examples, we considered it worthy to readdress this topic in order to get a more precise dating for this group of finds.
\end{abstract}

KEY WORDS: VIMINACIUM, KNEE FIBULA, SOLDIERS.

Generally speaking, knee fibulae got this name because of the shape of their bow which is sharply bent, resembling a human knee. The main feature of this type is a smaller or a bigger round head plate, which was often decorated. Below the grid there is a spring, often consisting of eight windings. All of the examples discovered at Viminacium possess an outer string, which is typical for Pannonia, Noricum, Dacia, Dalmatia, Upper and Lower Moesia. Contrary to this, inner strings afe typical for Raetia, Germania and Britannia. ${ }^{1}$ Bows can be of semi-spherical, triangular or trap-

1 Böhme 1972, 19-20. ezoidal cross-section. Top of the foot is often decorated with button- or thorn-like shapes. Narrow, sometimes very high needle holder is rectangular in shape and always placed longitudinally to the bow.

Apart from the opinion that this type of fibulas originates from the Noric-Pannonian region, ${ }^{2}$ there is also a hypothesis that they orinigate from the German-Raetian area. ${ }^{3}$ Frequent finds of these fibulas along the Rhine and the Danube limes led A. Böhme to conclusion that their users mostly

2 Kovrig 1937, 120-121.

3 Böhme 1972, 19.

* The article results from the project: IRS - Viminacium, Roman city and legionary camp-research of material and non ma-
terial culture of inhabitants by using modern technologies of remote sensing, geophysics, GIS, digitalisation and 3D visu-
alisation (no 47018), funded by Ministry of Education, Science and Technological Development of the Republic of Serbia. 
were soldiers. ${ }^{4}$ Marking this type of fibulas as type 18/A in her typology, S. Petković indicates that this fibula-type is not encountered very often in the inland of the western parts of the Empire. ${ }^{5}$ Apart from the Danube provinces Pannonia, Dacia, Upper and Lower Moesia, this type of finds is often encountered at Sarmatians along the left Danube bank, ${ }^{6}$ as well as in Thrace and Pontic cities. ${ }^{7}$ In the cities of the mentioned provinces, like Brigetio, Flavia Solva, Siscia and Napoca, semifabricates were discovered, as well as models and moulds for casting this type of fibulas. ${ }^{8}$ According to the great number of finds from Novi Banovci, S. Petković assumed that the local workshop for their production existed there. This author, who studied the area of modern Serbia, presented 76 finds of this type, ${ }^{9}$ out of which 19 come from Viminacium and were already published. ${ }^{10}$ Ten examples from Viminacium should be added, making a total number of 29 pieces. In this paper, apart from six severely damaged specimens, all of them shall be presented. Apart from the already mentioned sites in our country, similar finds were discovered at the following sites: Hrtkovci, Beška, Kovin, Mačvanska Mitrovica, Ušće, Kosmaj, Ritopek, Sapaja, Čezava, Ravna, Diana, Gamzigrad, Horreum Margi, Gornje Štiplje, Paraćin, Kolivrat and Ulpijana.

Regarding chronology of this fibula type, we should mention the Deutsch-Altenburg site, on which, in grave nr. 26 a similar piece was found along with Hadrian's coin and a belt-set which dates from the time of this emperor until the end of the $2^{\text {nd }}$ century, ${ }^{11}$ as well as the well-known grave of a soldier from Lion in which, apart from this fibula, a belt-set VTERE FELIX was discov-

4 Böhme 1972, 52-53.

5 Petković 2010, 129.

6 Petković 2010, 129.

7 Ambroz 1966, 28 T. 6, 16,18; Genčeva 2004, 48, T. XIV, 5

8 Petković 2010, 130.

9 Petković 2010, 133-138.

10 Redžić 2007, 33-35, T. XIV-XV, 138-156.

11 Ertel et al. 1999, 137, Taf. 25, 8. ered, along with a sword with a scabbard and 13 coins, out of which the youngest one was minted in 194. P. Wuilleumier brought this grave in connection with the battle of Lion in 197, fought between Septimius Severus and Claudius Albinus. ${ }^{12}$

Out of the fibulas presented here, six contributes to a more precise dating of this type. According to this, we should mention fibula nr. 6, which was discovered in a grave with three coins, out of which two were minted during the reign of Trajan and Hadrian, while the third dates into the first half of the $1^{\text {st }}$ century. Piece nr. 8 was discovered in a grave with a coin of Faustina the Younger, dated into 145-146, while the example nr. 16 was discovered in a grave with a coin of Faustina the Elder. Fibula nr. 3 was discovered in a grave with an oil-lamp stamped FAOR, as well as with two pottery vessels dated into the $2^{\text {nd }}$ century, while the example from the grave was discovered with two pottery vessels dated into the second half of the $2^{\text {nd }}$ and the beginning of the $3^{\text {rd }}$ century. Probably the youngest, but also chronologically the least reliable example is nr. 9, discovered in a layer with a knee fibula with a hinge, as well as with several coins from the first half of the $3^{\text {rd }}$ century, the youngest being two examples of Alexander Severus.

If we take a look at the dates indicated above, they show that knee fibulas with spring and round head plate were used from the second quarter of the $2^{\text {nd }}$ century and most intensively used from the middle of the $2^{\text {nd }}$ to the beginning of the $3^{\text {rd }}$ century, also supported by A. Böhme. ${ }^{13}$ A single find nr. 9 indicates that this fibula type was probably used even up to the middle of the $3^{\text {rd }}$ century.

Three variants of this type were distinguished according to the presence or absence of ornaments on the round head plate.

12 Wuilleumier 1950, 146-148.

13 Böhme 1972, 19. 


\section{VARIANT 1. T. I/1-12, T. II/13-18}

The main feature of this variant is its grid without any ornaments. W. Jonst defines these fibulas as his variant $\mathrm{C}$, stating that they were discovered in Britannia, along the Rhine and the Danube limes and in the Alps. ${ }^{14}$ In the Varna museum, several examples of this fibula type are kept, indicating that they were also worn along the coast of the Black Sea. ${ }^{15}$

Silver fibula with fragmented needle.

Discovered at the "Više grobalja" site, 1984, C-5162.

Length: $2,8 \mathrm{~cm}$.

Published: Redžić 2007, 33, T.XIV, 138; Petković 2010, 136, kat. br. 666 .

The fibula was discovered in grave G-780.

Completely preserved bronze fibula.

Discovered at the "Više grobalja" site, 1984, C-2373.

Length: $3,5 \mathrm{~cm}$. Published: Zotović, Jordović 1990, 105, T. CLXXXIV/5; Redžić 2007, 33, T.XIV, 139; Petković 2010, 136, cat. nr. 665.

The fibula was discovered in grave $\mathrm{G}_{1}-245$ with a pottery vessel dated into the $2^{\text {nd }}$ and $3^{\text {rd }}$ century.

Bronze fibula with a missing needle.

Discovered at the "Više grobalja" site, 1984, C-7278.

Length: $2,6 \mathrm{~cm}$.

Dating: $2^{\text {nd }}$ century.

Published: Redžić 2007, 33, T.XIV, 140; Petković 2010, 136, cat. nr. 667.

The fibula was discovered in grave $\mathrm{G}_{1}-1038$, along with a FAOR oil-lamp and two pottery vessels dated into the $2^{\text {nd }}$ century.
Bronze fibula with fragmented needle.

Discovered at the "Pećine" site, 1983, C-10465.

Length: $3,3 \mathrm{~cm}$.

Dating: $2^{\text {nd }}$ century, according to accompanying finds.

Published: Redžić 2007, 33, T.XIV, 141; Petković 2010, 136, cat. nr. 674 .

The fibula was discovered in grave G-3477 along with a coin dated into the $1^{\text {st }}$ and $2^{\text {nd }}$ century.

Bronze fibula with fragmented needle.

Discovered at the "Više grobalja" site, 1985, C-11826.

Length: $3,4 \mathrm{~cm}$.

Published: Redžić 2007, 33, T.XIV, 142; Petković 2010, 136, cat. nr. 668 .

The fibula was discovered in grave G-2103.

Completely preserved fibula.

Discovered at the "Više grobalja" site, 1984, C-6013.

Length: $3,7 \mathrm{~cm}$.

Dating: second quarter of the $2^{\text {nd }}$ century.

Published: Redžić 2007, 33, T.XIV, 143; Petković

2010, 136, cat. nr. 669 .

The fibula was discovered in grave $\mathrm{G}_{1}-798$ along with three coins, out of which two were minted during the reign of Trajan and Hadrian, while the third one dates into the first half of the $1^{\text {st }}$ century.

7. Completely preserved bronze fibula.

Discovered at the "Više grobalja" site, 1985, C-9470.

Length: $3,3 \mathrm{~cm}$.

Published: Redžić 2007, 33, T.XIV, 144; Petković 2010, 136, cat. nr. 670 .

The fibula was found in grave G-1396, along with a knee fibula with a square head plate, as well as a coin from the $1^{\text {st }}$ century, not relevant for the dating.

14 Jobst 1975, 65.

15 Хараланбиева, Андреева 2000, 5-17. 
Bronze fibula with fragmented needle.

Discovered at the "Pećine" site, 1983, C-7329.

Length: $3,5 \mathrm{~cm}$.

Dating: middle of the $2^{\text {nd }}$ century, according to accompanying finds.

Published: Redžić 2007, 34, T.XIV, 145; Petković 2010, 137, cat. nr. 675 .

The fibula was discovered in grave $\mathrm{G}_{1}-661$ along with a coin of Faustina the Younger, dated into 145-146 (RIC 1398).

Bronze fibula with fragmented needle.

Discovered at the "Velika kapija" site, 1979, C-267.

Length: $3,5 \mathrm{~cm}$.

Dating: first half of the $3^{\text {rd }}$ century, according to accompanying finds.

Published: Redžić 2007, 34, T.XIV, 146; Petković 2010, 137, cat. nr. 680 .

It was discovered in the same layer with a knee fibula with a hinge as well as some coins from the first half of the $3^{\text {rd }}$ century, the youngest ones being the two examples of Alexandar Severus.

Bronze fibula with fragmented needle.

Discovered at "Kod bresa" site, 1987, C-421.

Length: $3,5 \mathrm{~cm}$.

Published: Redžić 2007, 34, T.XIV, 147; Petković 2010, 137, cat. nr. 681.

Bronze fibula with fragmented needle.

Discovered at the "Pećine" site, 1983, C-8535.

Length: 4,2 cm.

Published: Redžić 2007, 34, T.XIV, 148; Petković 2010, 137, cat. nr. 676.

Bronze fibula with fragmented needle.

Discovered at the "Pećine" site, 1983, C-9828.

Length: $3,3 \mathrm{~cm}$.

Published: Redžić 2007, 34, T.XIV, 149; Petković 2010, 137, cat. nr. 677.
Bronze fibula with fragmented needle.

Discovered at the "Više grobalja" site, 1984, C-2899.

Length: $3,8 \mathrm{~cm}$.

Published: Redžić 2007, 34, T.XIV, 150; Petković

2010, 136, cat. nr. 671.

Completely preserved bronze fibula.

Discovered at the "Više grobalja" site, 1985, C-9401.

Length: $3,6 \mathrm{~cm}$.

Published: Redžić 2007, 34, T.XIV, 151; Petković

2010, 136, cat. nr. 672 .

15. Completely preserved bronze fibula.

Discovered at the "Više grobalja" site, 1985, C-9261.

Length: $3,8 \mathrm{~cm}$.

Dating: secong half of the $2^{\text {nd }}$ and the beginning of the $3^{\text {rd }}$ century, according to the accompanying finds.

Published: Redžić 2007, 34, T.XIV, 152.

The fibula was discovered in grave $\mathrm{G}_{1}-1362$ along with two pottery vessels dated into the second half of the $2^{\text {nd }}$ and the beginning of the $3^{\text {rd }}$ century.

16. Completely preserved bronze fibula.

Discovered at the "Kod koraba" site, 2005, C-208.

Length: $3,8 \mathrm{~cm}$.

Dating: $2^{\text {nd }}$ and the first half of the $3^{\text {rd }}$ century.

Published: Redžić, Jovičić 2011, T. II, 15;

Found in a cremated grave $\mathrm{G}_{1}-66$ along with a coin of Faustina the Elder.

17. Completely preserved bronze fibula.

Discovered at the "Lugovi" site, 1983, C-31.

Length: $3,3 \mathrm{~cm}$.

Unpublished.

18. Bronze fibula with a missing needle.

Discovered at the "Selište", 1991, C-75.

Length: $3,3 \mathrm{~cm}$.

Unpublished. 


\section{VARIANT 2: T. II/19-22}

This variant differs from the first one only owing to the decorated grid. It includes three examples from our collection. The decoration in the shape of simple incisions or zig-zag lines is often encountered on the edge of the grid, sometimes in its middle. W. Jobst defined these fibulas as his variant D. ${ }^{16}$

19. Completely preserved bronze fibula.

Discovered at the "Više grobalja" site, 1984, C-3805.

Length: $4,4 \mathrm{~cm}$.

Published: Redžić 2007, 34, T.XV, 153; Petković 2010, 136, cat. nr. 673 .

The fibula was discovered in grave G-543.

20. Bronze fibula with fragmented needle.

Discovered at the "Pećine" site, 1986, C-11855.

Length: $2,5 \mathrm{~cm}$.

Publikovano: Redžić 2007, 34, T.XV, 154; Petković 2010, 137, cat. nr. 678.

The fibula was discovered in grave G-4851.

21. Bronze fibula with fragmented needle.

Discovered at the "Pirivoj" site, 2004, C-578.

Length: $3.8 \mathrm{~cm}$.

Published: Redžić 2007, 34, T.XV, 155; Petković 2010, 137, cat. nr. 682 .

22. Completely preserved bronze fibula. The edge of the grid is decorated with a carved zig-zag line. Discovered at the "Na kamenju" site, 2007, C-79. Length: $3,7 \mathrm{~cm}$.

Published: Redžić, Jovičić 2011, T. II, 14;

16 Jobst 1975, 66 .

\section{VARIANT 3: T. II/23}

Only one example made of silver belongs to this variant, possessing semi-circular cuttings at the lower part of the grid. Similar examples were discovered in Zugmantel. ${ }^{17}$

23. Silver fibula with fragmented needle.

Discovered at the "Pećine" site, 1979, C-1622.

Length: $3,6 \mathrm{~cm}$.

Published: Redžić 2007, 35, T.XV, 156; Petković

2010, 137, cat. nr. 679 .

\section{BIBLIOGRAPHY}

\section{Амброз 1966}

А. К. Амброз, Фибулы јога европейской части CCCP II в. до. з. - IV в.н.з., Москва 1966.

\section{Bojović 1983}

D. Bojović, Rimske fibule Singidunuma, Beograd 1983.

\section{Böhme 1972}

A. Böhme, Die Fibeln der Kastelle Saalburg und Zugmantel, Saalburg Jahrbuch XXIX, Saalburg 1972.

\section{Ertel 1999}

C. Ertl, V. Gassner, S. Jilek, H. Stieglitz et alli., Untersuchungen zu den Gräberfeldern in Carnuntum, Band 1: Der archäologische Befund. Der römische Limes in Österreich 40, Wien 1999.

\section{Ettlinger 1973}

E. Ettlinger, Die römischen Fibeln in der Schweiz, Bern 1973.

\section{Генчева 2004}

Е. Генчева, Римските фибули от Бьлгария, Велико Тьрново 2004.

17 Böhme 1972, 19, T. 7, 390-391. 


\section{Хараланбиева, Андреева 2000}

А. Хараламбиева, Е. Андреева, Провинциалноримски коленчати фибули във Варненския археологически музей, Известия на народния музей Варна, книга 30-31 (45-46), 1994-1995, Варна 2000, 5-18.

\section{Jobst 1975}

W. Jobst, Die römischen Fibeln aus Lauriacum, Linz 1975.

\section{Kovrig 1937}

I. Kovrig, Die Haupttypen der kaiserzeitlichen Fibeln in Pannonien, Dissertationes Pannonicae, II/4, Budapest 1937.

\section{Petković 2010}

S. Petković, Rimske fibule u Srbiji od I do V veka n. e., Beograd 2010.

\section{Redžić 2007}

S. Redžić, Nalazi rimskih fibula na nekropolama Viminacijuma, Beograd 2007.

\section{Redžić, Jovičić 2011}

S. Redžić, M. Jovičić, Nepublikovani nalazi rimskih fibula sa teritorije Viminacijuma, Arheologija i prirodne nauke 7, Beograd 2011.

\section{Zotović, Jordović 1990}

Lj. Zotović, Č. Jordović, Nekropola „Više Grobalja“, Viminacium I, Beograd 1990.

\section{Wuilleumier 1950}

P. Wuilleumier, La bataille de 197, Gallia 8, 1950 , 146-148.

\section{REZIME}

KOLENASTE FIBULE SA OPRUGOM

I POLUKRUŽNOM POTPORNOM

GREDOM SA TERITORIJE VIMINACIJUMA

\section{KLJUČNE REČI: VIMINACIUM, KOLENASTA FI- BULA, VOJNICI.}

Konstantan rad na istraživanju viminacijumskih nekropola, ali i stambenih celina, znatno doprinosi preciznijem datovanju arheoloških nalaza i kulturnih spomenika Rimskog carstva. Imajući to $u$ vidu, na osnovu nalaza iz grobnih celina sa Viminacijuma, ali i drugih lokaliteta smatram da kolenaste fibule sa oprugom i polukružnom potpornom gredom počinju da se koriste najranije tokom druge četvrtine II veka, a da se period njihove pune primene kreće $u$ intervalu od sredine II, pa do početka III veka. Ipak nalaz primerka broj 9 u sloju sa novcem prve polovine III veka ukazuje na mogućnost korišćenja fibula ove vrste do sredine III veka. 

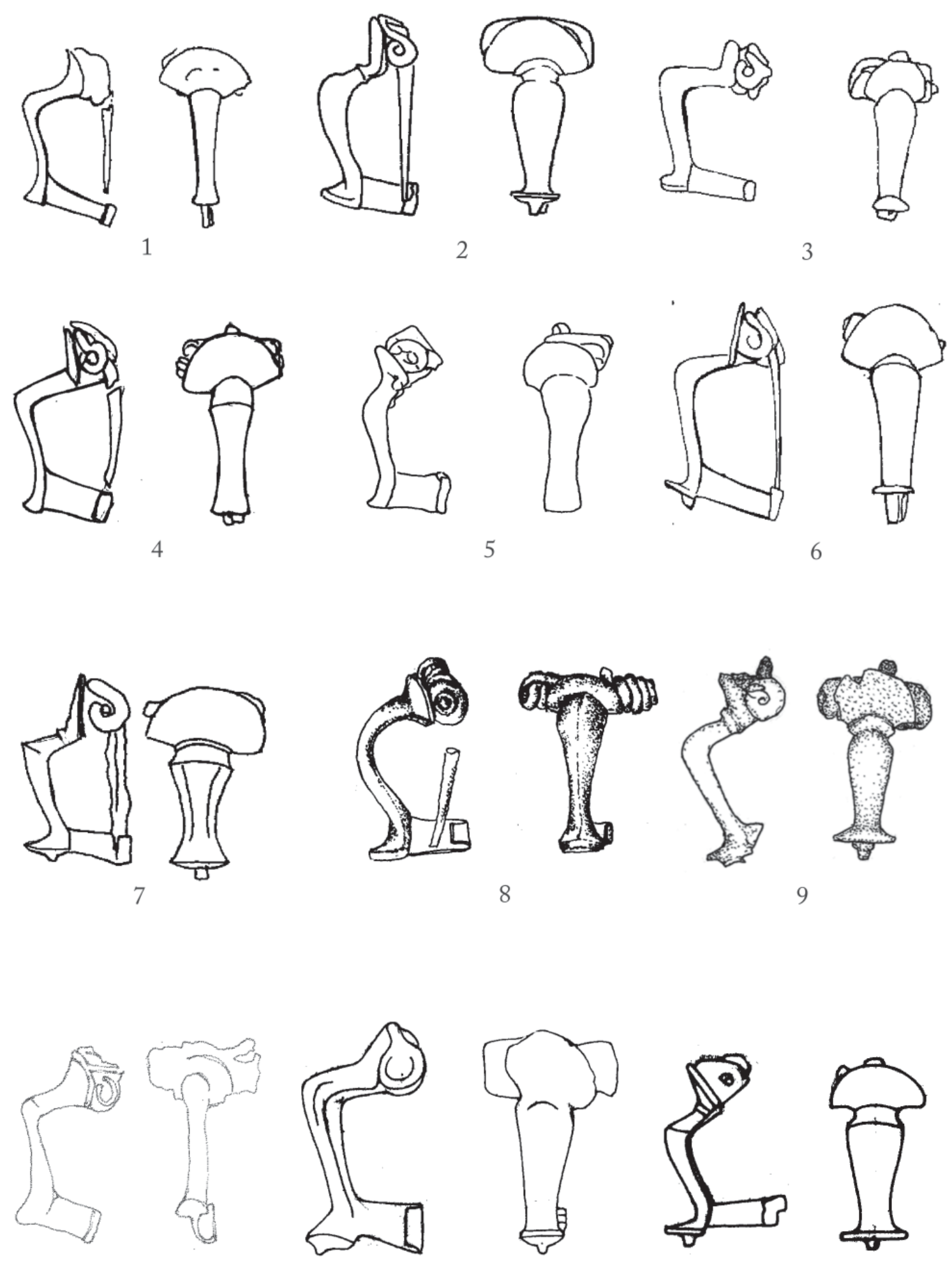

11

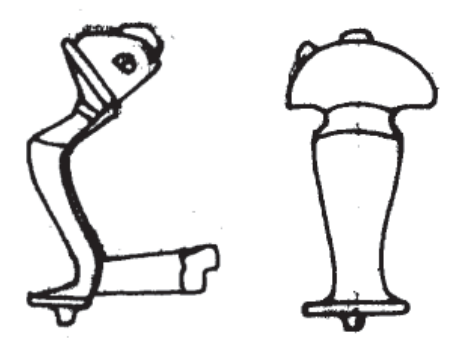

12

T.I 1-12, Varijanta 1 


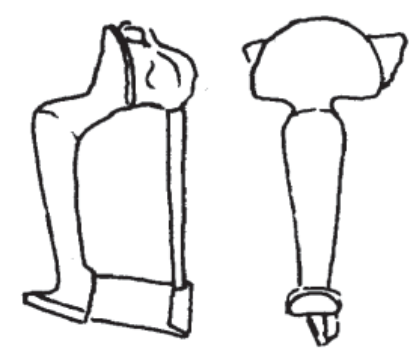

13

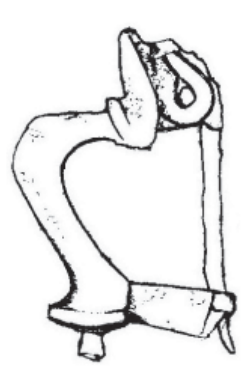

16

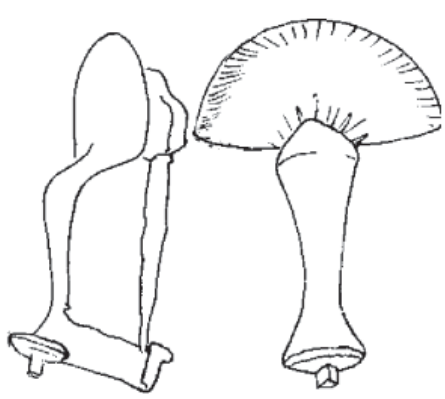

19

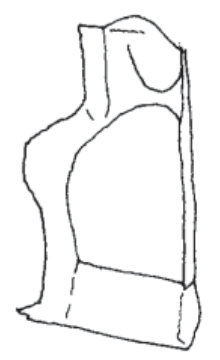

14
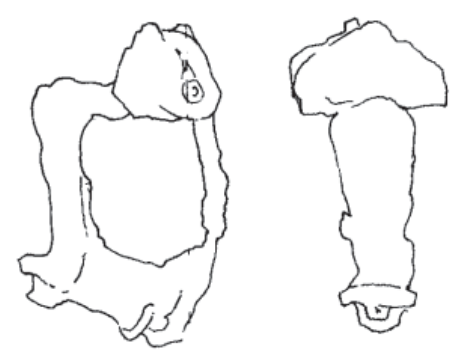

15
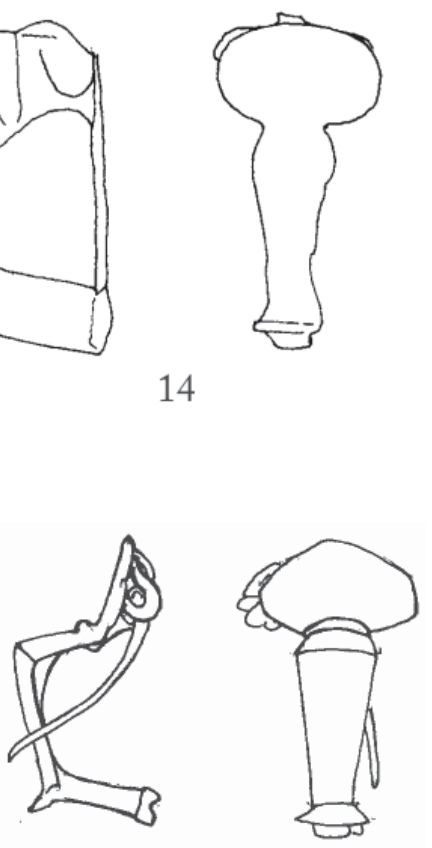

17

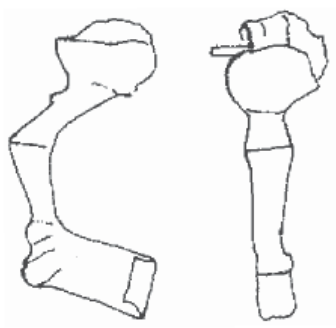

18

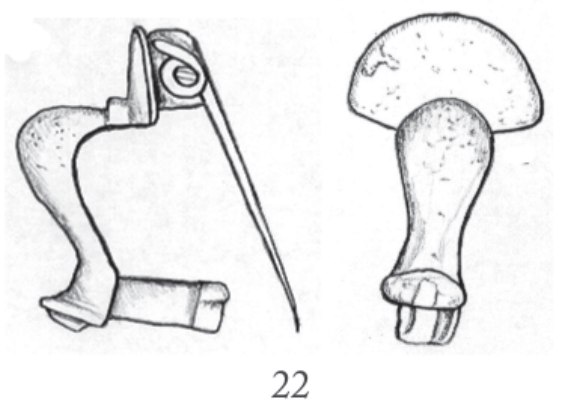

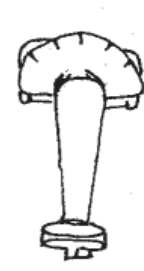

20

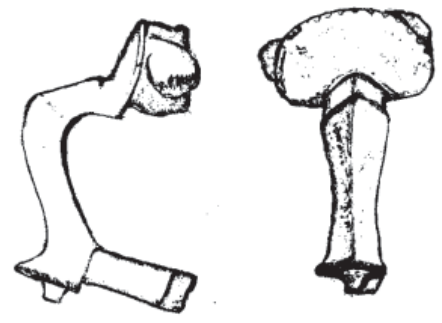

21

T.II 13-18 Varijanta 1, 19-22 Varijanta 2, 23 Varijanta 3 